\title{
The relationship between gender equality activity in organizations and employee perceptions of equality
}

\author{
Arney Einarsdóttir, Katrín Ólafsdóttir and Laura Nesaule ${ }^{1}$
}

\begin{abstract}
A persistent unexplained gender wage gap exists in Iceland and women are still in a minority as directors, chairs of boards and board members within organizations. Organizations are required by law to have a gender equality statement, but in addition they may be taking various proactive actions towards equality. However, little knowledge exists on whether these actions lead to more positive perceptions of equality amongst employees. The main objective of this study is therefore to study the relationship between organizational gender equality activity (existence of a gender equality statement and Organizational Equality Maturity (OEM)) and employee perceptions of equality, as well as to explore whether minimum legally required actions and OEM have a positive influence on employees in the workplace.

This is the first study in Iceland to evaluate organizational equality activity against employees' perceptions of equality. The study was executed at two levels and is time-lagged, first among 35 HRM managers and then a few months later among 1041 employees in the same 35 organizations. The results show that when organizations reach higher Organizational Equality Maturity, employee perceptions of gender equality in the workplace are positively influenced. The influence is primarily on employee perceptions of top management and on hiring and promotional activities. The results contribute towards a better understanding of how gender equality activity in organizations affects employees, which has practical implications for management and HRM practitioners.
\end{abstract}

JEL flokkun: M12; M14; M51; J16

Keywords: Gender equality; gender equality statement (jafnréttisáætlun); Organizational Equality Maturity; employee perceptions of equality.

1 Arney Einarsdóttir, Assistant Professor, Faculty of Business Administration, University of Iceland. E-mail: arney@hi.is. Katrín Ólafsdóttir, Assistant Professor, Reykjavik University School of Business. E-mail: katrino@ru.is. Laura Nesaule, MSc in Human Resource Management and Organizational Psychology. E-mail: laura.nesaule@landsvirkjun.is.

This work is licensed under a Creative Commons Attribution 4.0 License.

DOI: https://doi.org/10.24122/tve.a.2018.15.1.2

(C) Tímarit um viðskipti og efnahagsmál

www.efnahagsmal.is 


\section{Introduction}

Despite women's active participation in the labor market in Iceland, achievements in educational attainment in recent years, and Iceland repeatedly ranking number one on the Gender Gap Index published by the World Economic Forum (World Economic Forum, 2016), studies still indicate a $7.6 \%$ unexplained wage gap, after controlling for work hours, job title, age, tenure, and education (Snaevarr, 2015). This unexplained wage gap can be expected to affect women throughout both their working and retirement lives. In addition, women have only a 20-25\% representation in management and on organizational boards (Statistics Iceland, 2018). Recent studies also show that women in middle management still experience barriers and various types of stereotyping, and a lack of appreciation of their qualities (Einarsdottir, Kristjansdottir, \& Christiansen, 2017). Experiments also indicate persistent bias in various HRM-related decision-making in Iceland (Karlsson, Jonsdottir, \& Vilhjalmsdottir, 2007) and elsewhere (MacNell, Driscoll, \& Hunt, 2015; Moss-Racusin, Dovidio, Brescoll, Graham, \& Handelsman, 2012).

Discrimination based on gender is explicitly prohibited in the constitution of most EU countries, and in addition many have adopted provisions pertaining specifically to equality between men and women (Timmer \& Senden, 2016). Despite EU directives and national laws and regulations attempting to address gender equality, gender based discrimination still exists in various forms in the member states (European Commission, 2016; Timmer \& Senden, 2016). The same applies to Iceland (Olafsdottir, 2018).

While laws and regulations that stipulate behavior in organizations are important for improving gender equality in the labor market, other factors also play a role. It has been suggested that the societal role of organizations and the role of human resource management (HRM) in the labor market may be undervalued (Zanoni, Janssens, Benschop, \& Nkomo, 2010). With respect to gender equality, it has been proposed that the field of corporate social responsibility (CSR) and company stakeholders' relations could contribute to the broader EU gender and sustainability objectives (Grosser, 2009). However, others warn that leaving equal opportunity solely to organizations is a precarious foundation for the improvement of the situation of women and ethnic minorities (Dickens, 1999). Dickens (1999) therefore proposes a three-pronged or tripod approach in order to reach real achievements of equality: by legal actions; by social regulations through social partners; and by a long-term commitment by organizations to move beyond the business case.

While fulfilling legal requirements is important, it may not be enough, even though these requirements provide the general and in some cases specific minimum guidelines and rules by which organizations must abide. Organizational proactivity, or organizational corporate social responsibility, through management is also an important factor for equality actions to be effective and to be transferred to and experienced by the direct stakeholders, namely the employees of the respective organizations. Still, no prior attempts have been made in Iceland to study organizational activity (commitment and proactivity) in relation to their equality activities, and its influence on employees has not been examined. The main objective of this paper is to study the relationship between organizational gender equality activity (the existence of a quality statement and the level of Organizational Equality Maturity) and employee perceptions of equality. First, it will be examined whether the existence of the legally required equality statement (jafnréttisáxtlun) influences employee perceptions of organizational equality. Then the influence of Organizational Equality Maturity on employee perceptions of equality (reaching effective upper stages of proactive activity) is examined -when organizations go beyond the minimum legal requirements and engage in more proactive and committed gender equality activities. 


\section{Theoretical and legal background}

\subsection{Gender bias in organizations}

Icelandic women have the highest labor force participation rate among the OECD countries (OECD, 2016), some $86.2 \%$ in the first quarter of 2017, and Iceland and Sweden are the only OECD countries where the female labor force participation rate reaches $80 \%$. On average, the women's labor force participation rate in the OECD countries is $63.6 \%$. Women have also surpassed men in their educational attainment, as over half (56\%) of Icelandic women in the labor market have completed tertiary education, as compared to $44 \%$ of Icelandic men (Statistics Iceland, 2017a). Although relatively developed in international comparisons on gender equality (World Economic Forum, 2016), on women's active labor force participation and educational attainment, there is still a way to go in Iceland before full equality is reached (Olafsdottir, 2018). Wages are one of the equality components most easily and reliably measured, and there exist unexplained wage differentials between the genders in wage regressions in Iceland (Olafsdottir \& Rognvaldsdottir, 2015; Snaevarr, 2015). The legal environment along with other organizational activity have therefore not yet provided full gender equality.

In addition to a gender wage differential, various studies and experiments indicate that decision-making in organizations is affected either by gender stereotyping or by unconscious bias on behalf of management (Olafsdottir \& Rognvaldsdottir, 2015). Identifying and eradicating bias in less easily measured decision-making, such as hiring, promotions, training opportunities, and other non-monetary benefits is much harder than measuring the wage differential. To demonstrate how prevalent and strong biases are in organizational decision-making in general, a few experimental studies are noteworthy here. In a nationwide experiment, amongst science faculty from research-intensive universities in the U.S., participants were asked to rate application material from a student applying for a laboratory manager position (Moss-Racusin et. al., 2012). The application was randomly assigned either a male or a female name. Faculty participants rated the male applicant as significantly more competent and hireable than the identical female applicant, they selected a higher starting salary for the male, and offered more career mentoring to him than to her. Both female and male faculty members evaluating the applicants were equally likely to exhibit bias against the female student.

Another experiment executed in Iceland (Karlsson et. al., 2007) also indicated a bias in wage decision-making upon hiring. When women and men were asked to evaluate applications for a fictional job, resumés with a female name led to lower wage offers than to male ones, despite otherwise identical content. Participants evaluating applicants also recommended that women ask for lower wages than men. Women and men were equally likely to exhibit bias against female applicants. In another experiment carried out in an online course, two instructors - one male and one female - taught two groups each, one as their own gender and the other as the opposite gender (2-by-2 experimental design). Although the courses were taught in the same manner, students rated the identity of the male instructor as higher than the female identity regardless of the actual gender of the instructor (MacNell, Driscoll, \& Hunt, 2015). This again demonstrates how persistent gender biases are.

Gender inequality has its roots in different and biased expectations assigned to employees based on gender (Bruckmüller, Ryan, Rink, \& Haslam, 2014; Ellemers, Rink, Derks, \& Ryan, 2012). These biases contribute towards the well-known metaphor of glass ceilings preventing women from reaching top management positions, and glass-cliffs explaining that women who have broken through the class ceiling fall more easily off the cliff when the firms are not doing well. Sticky floors refer to women being stuck at the bottom of the wage scale even when promoted into higher positions. The leaking pipelines metaphor, on the other hand, explains that despite the pipeline theory, which suggests that women will 
advance naturally up the ladder when higher educational attainment is reached and organizations actively engage in gender equality activity (thus suggesting that specific laws are not required), women still fall out of the pipeline. Finally, the metaphor of labyrinths is intended to explain the complexity of the various barriers and opportunities that women face at all levels in organizations, including biases and stereotyping (Carli \& Eagly, 2016).

According to the pipeline theory ( Carli \& Eagly, 2016), women in Iceland should progress naturally in organizations due to their educational achievement, active labor market participation, and various activities undertaken by organizations, as required by law (see a more in-depth discussion about the legal framework in section 2.2). However, the pipeline seems to be leaking as only $22.1 \%$ of directors are women, $23.9 \%$ of chairs of boards and 25.9\% of board members in 2016 (Statistics Iceland, 2018). The gender biased stereotyping in decision-making is strong and persistent within the organizational world. Subtle discrimination may be the main problem as this is more difficult to detect, measure, and address than blunt and measurable discrimination. Subtle discrimination may also be the foundation for the glass ceiling, the slippery glass cliff, the leaking pipeline, the sticky floor, the labyrinth, and the stalling of gender equality improvements (Van Laer \& Janssens, 2011).

The existence of gender-based biases and subtle discrimination further underlines the need for proactive and committed gender equality policy and proactive actions on behalf of organizations in HRM-related activities and decision-making. In addition, Cornelius (2002) has pointed out that a gap may exist between HRM hoped-for results and actual outcomes. Outcomes may also be difficult to measure objectively at the organizational level. It is therefore argued here that the relationship between gender equality activities and employee perceptions of equality in various HRM domains should be one of the outcomes of interest to academics and practitioners. Knowing whether organizational activity affects employee perceptions of equality may also be one reference point when discussing and evaluating whether gender equality programs are effective, or their outcomes positive.

\subsection{The legal framework of equality}

Gender equality is an important and long-lasting priority for the EU, and is even integral to its sustainability strategy (see i.e. in Grosser, 2009), as in recent years directives have increasingly addressed it (Timmer \& Senden, 2016). Furthermore, gender equality is also part of the global agenda of the United Nations, as presented in its sustainable development goals (United Nations, n.d.). Many EU directives address equality in the organizational context for employees, including equal pay. It may still take some time for individual countries to implement EU gender equality policies at the national level. In the Netherlands it took 14 years to implement article 119 on Equal Pay in their national laws (see in Verloo, 2005). In Iceland, not all organizations fulfil the legal requirement to have a gender equality statement fifteen years after a national law was passed (Einarsdottir, Olafsdottir, \& Bjarnadottir, 2015).

The Icelandic Constitution (33/1944), similarly to many constitutions in EU countries (Timmer \& Senden, 2016), includes both a broad anti-discrimination provision and a special provision on equal rights for women and men. The first equality law was passed and a Gender Equality Council was founded in 1976 in Iceland (Centre for Gender Equality Iceland, 2017). The minimum and specifically stated actionable legal requirement directed towards organizations is declared in the Act on Equal Status and Equal Rights of Women and Men (10/2008). The act explicitly states that employers are prohibited from discriminating based on gender when determining wages and benefits. Furthermore, the burden of proof is placed on the employer. The same burden of proof on the employer applies to promotions and layoffs according to the act.

An important amendment requiring easily measurable management activity came into effect in 2000 (Jafnréttisstofa, 2017), requiring organizations with more than 25 employees 
to either address gender equality in their HRM strategy or have a gender equality statement (jafnréttisáxtlun), and to set equality-related goals. In 2015, 15 years later, a gender equality statement still did not exist in $13 \%$ of organizations with 70 or more employees (Einarsdottir et al., 2015).

Another notable amendment to the Act on Equal Rights (10/2008) was made in 2008 and is directly intended to decrease wage discrimination and increase wage transparency, and reflects a general trend towards pay openness and open-access culture, referred to as pay transparency in the workplace (Marasi \& Bennett, 2016). The act revokes wage secrecy as it explicitly states that employees are always allowed to inform others about their wages. Still relatively little awareness and discussion seem to exist relating to this amendment and no information is available on its impact. Another act from 2010 states that organizations with more than 50 employees must ensure that their boards consist of a minimum of $40 \%$ of either gender (see f.e. in the Centre for Gender Equality Iceland, 2017). The law is the first quota law relating to gender equality in Iceland and its requirements are explicitly actionable for organizations that do not fulfil them as they are easy to objectively measure by a third party. The law took full effect in 2013 but does not stipulate any sanctions and as stated above, three years later in 2016 women sat on only a quarter $(25.9 \%)$ of seats on boards (Statistics Iceland, 2018).

The latest amendment to the existing legislation directly addresses the gender wage gap and came into effect in 2018. It requires organizations with 25 or more employees to acquire an equal wage certification by a third party based on the Equal Pay Standard (Act on Equal Rights of Women and Men (An Equal Wage Certification)) no. 56/2017; Act on Equal Status and Equal Rights of Women and Men no. 10/2008). It is intended to certify that the value of jobs and the process of wage determination are gender neutral.

All in all, the direction of the legal requirements in Iceland is towards an increased focus on requiring measurable proof by the employer, either overall, within the organization, or in individual cases. The development of an equality statement and goals is only the first step for organizations intending to improve organizational equality. Its pure existence on paper does not guarantee its translation into actions. Organizations may, for example, create such documents half-heartedly to "check the box", or to provide the proof of fulfilment of the legal requirements. In some cases organizations may simply "copy and paste" such policies from other organizations to fulfil the legal requirement instead of developing their own policy reflecting and addressing their unique challenges or weaknesses. Hence, a more proactive and committed activity on behalf of management may not necessarily follow the existence of a gender equality statement. There is a long way from international, European, national, and state-level legal requirements enforced through directives, laws and regulations to organizational-level initiatives, corporate social responsibility, and organizational gender equality in action. For an organization committed to promoting equality it is therefore critical to be proactive and committed and not merely wait for legislation to be passed.

A great deal of research exists on the outcome of equality (Olafsdottir \& Rognvaldsdottir, 2015), while little is known about the impact of different actions on employees' perceptions. It is therefore of interest and timely to study whether the mere existence of a gender equality statement affects the most direct stakeholders: the employees. The first research question is whether organizational fulfilment of the legal requirement to have an organizational equality statement (policy and goal setting) affects employee perceptions of equality in the workplace.

\subsection{Organizational equality: Maturity and perceptions}

Corporate Social Responsibility (CSR) is commonly defined as entities' (organizational) responsibility for their economic, legal, ethical and philanthropic actions (Carroll, 1999). CSR increasingly focuses on how products and services are made and delivered in the pro- 
duction chain by organizations, encompassing responsibility for employees directly employed as well as for those employed by suppliers within the supply chain (Grosser, 2009). CSR also builds on stakeholder theory (Freeman, 1984) which defines stakeholders as any group or individual who either can affect or be affected by organizational goal achievement. When referring to CSR and organizational activity, it is interpreted and suggested here that attempts to abide by existing equality legislation is only the first step towards a responsible "citizenship" to improve gender equality and take responsibility for equality within organizations. Assessments of the impact of activity or evaluation of the status takes the organizational responsibility and proactivity a step further. The employees are on the receiving end of the organizational-level activities as the key stakeholders working and receiving remuneration for both their work and various types of work-related opportunities, such as participating in decision-making, career developments, promotions and pay, which can all be classified as HRM-related decisions.

As mentioned above, Dickens (1999) suggests that a three-pronged or tripod approach be used to address limitations and to go beyond the so-called business case for equality. He concludes that the role of top management, HRM and line managers is critical for providing equal opportunities to all employees within organizations. A broad concept of strategic human resource maturity (Strategic HRM) by Kearns $(2003,2010)$ describes in general terms how organizations can develop sequentially and progress from one maturity stage to another to become more strategically aligned and mature in their general HRM activity. The chain starts with no conscious HRM in stage zero, moves to strategic maturity and effectiveness at stage three, and ends with the organization becoming a whole system at stage six. Five stages of Strategic HRM maturity have been operationalized and used in studies executed among HRM managers (data collected from HRM managers about HRM practices and Strategic HRM maturity) every three years in Iceland since 2006. Results indicate a steady progressive improvement in Strategic HRM maturity in Icelandic organizations since 2006 (Einarsdottir, Bjarnadottir, \& Oddsson, 2009; Einarsdottir, Bjarnadottir, Olafsdottir, \& Georgsdottir, 2012; Einarsdottir et. al., 2015; Oddsson, Bjarnadottir, \& Einarsdottir, 2006). This study builds on Kearns' notion of maturity and the operationalization for Strategic HRM maturity. The general concept of maturity for HRM/Strategic HRM in this study is adjusted to evaluate organizational level proactivity specifically in the field of gender equality using the term Organizational Equality Maturity (OEM).

The concept of OEM is conceptualized and operationalized here for the purpose of this study at the organizational level, thereby attempting to capture organizational proactivity and responsible "citizenship." It includes five predefined stages (from 0 to 4 ) in line with Kearns's (2003) general HRM maturity stages. At stage 0 no equality statement exists in the organization, while it exists at stage 1 but without a follow up or follow through activity. At stage 2 organizations have started primary work on various activities, f.e. analyzing wages by gender, and in general are working with gender equality at the board level and in committees. At stage 3 organizations have become quite active and should thus have become effective (in line with the original maturity stages), with a minimum of 3-4 progressive gender equality activities relating to jobs, wages, training and promotions. Organizations reaching stage 3 in maturity are thus defined as proactive and committed to equality within the organization. At stage 4 the system is described as well-established and extensive throughout the organization, including some form of an equality certification or acknowledgement by a third party, or a type of affirmative action approach. For the purposes of this study, organizations are classified into two groups: those that have reached stage 3 or above as mature, and those that are at stage 2 or below with low maturity.

Nishii, Lepak and Schneider (2008) proposed that perceptions precede attitudes in the causal link toward organizational performance, and that employee attributions of HRM, the source or reason why HRM practices are implemented, may matter. When organizations become strategic in their HRM practices, i.e. through attempting to reach clear strate- 
gic objectives in one area or another (f.e. such as in gender equality), employee perceptions become an important link in the causal chain towards organizational performance. It suggests that organizations and researchers alike might have to pay attention to the concept of employee perceptions of gender equality, in addition to focusing on wage gaps and gender representation in management and on boards. A few prior studies indicate that a link may exist between organizational equality efforts and equality within organizations (Bruckmüller, Ryan, Rink, \& Haslam, 2014; Creegan, Colgan, Charlesworth, \& Robinson, 2003; Ng \& Burke, 2004; Van Dijk, Van Engen, \& Paauwe, 2012) However, neither the discussion in general nor the studies focus directly and specifically on the relationship between organizational gender equality activity and employees' perceptions of equality. No prior study has empirically evaluated this relationship by collecting and using data or information acquired among both HRM managers and employees.

In summary, organizations are part of society and reflect their existing norms and values. Gendered biases are still present in organizations, which lead to persistent discrimination taking place in the workplace. Even though a great deal of research exists on the sources and state of inequality, the question that remains to be answered is how employees perceive organizational activity or the proactive corporate social responsibility on behalf of organizations in relation to gender equality. Therefore, this study also aims to answer the following research question: Do organizational proactivity and commitment, measured through Organizational Equality Maturity (OEM), positively influence employee perceptions of equality?

\section{Method}

\subsection{Participants and procedures}

This study was designed as multi-level, cross-sectoral and time-lagged. Data was first collected from 35 HRM directors and six months later from 1041 employees in their respective organizations. Data collection was executed in two phases as part of a larger survey for the International CRANET research on comparative strategic HRM. CRANET is an established collaborative network of researchers from more than 40 universities around the world, founded to meet the need for ready access to information on best practices and comparative HRM performance globally (Cranfield Network on International Human Resource Management, n.d.). Data for phase one was collected in spring 2015 through an electronic survey sent to all HR directors in both public and private organizations employing 70 or more employees, for a total of $322 \mathrm{HR}$ managers. Hence, rather than taking a sample, the research is based on the whole population of organizations in Iceland employing 70 or more employees. Altogether 119 HR managers participated in phase one, corresponding to a $37 \%$ response rate.

For data collection in phase two the HR managers who participated in phase one, and agreed to participate in phase two, provided either a random sample of 50 employees (their emails) or all employees from the respective organizations. The final sample consisted of $35(\mathrm{~N}=35)$ organizations, of which 22 are private organizations and 13 are public institutions. The data at employee level was collected in early 2016. A total of $2020 \mathrm{em}-$ ployees were in the sample and 1041 employees $(n=1041)$ participated by completing $50 \%$ of the survey or more, thus accounting for a response rate of $52 \%$. The second survey was also executed electronically, through employee emails.

The participants largely mirror the Icelandic labor market, which in 2015 consisted of $52.4 \%$ males and $47.6 \%$ females (Statistics Iceland, 2017b). However, proportionally more women than men participated in the survey as $54.9 \%$ were female and $45.1 \%$ were male. The mean age of the respondents was in the category 40-49 years old. In terms of their level of education, some $40.7 \%$ of the respondents did not hold university qualifications; the rest, $59.2 \%$, had a university education. About $34 \%$ of individuals in the Icelandic labor 
market had a university degree in 2015 (Statistics Iceland, 2017a) and therefore the sample is slightly skewed in the direction of a higher education. A total of $35 \%$ of respondents held managerial responsibility. This may be explained by the electronic execution of the survey as it may not have reached lower level employees who do not use a computer in their daily work and may not even have an assigned company email address.

\subsection{Measures and analysis}

At the organizational level in phase one of the data collection, the independent variables consisted of one variable measured among HR Directors asking whether an equality statement existed within the organizations. The item Existence of an Equality Statement shows whether this statement exists within an organization, assessed using a dichotomous variable, where no $=0$ and yes $=1$. Five organizations out of $35(14 \%)$ did not have an equality statement, corresponding to 123 employees out of the 1041 participants working in organizations that do not fulfill the legal requirement to develop an equality statement (jafnréttisáxtlun).

The question on Organizational Equality Maturity (OEM) was designed by the researchers as a scenario bi-polar question where stages 0-4 (from the worst to the best) were developed in order to mirror progressive stages of equality within the organization (see appendix A). The statement for stage 0 was as follows: "Equality statement does not exist, neither as a part of HRM nor as a special policy, and no specific activities have been implemented in the field of equality." The statement "Written equality statement exists and/or procedures exist on equality (or HRM policy which covers equality) as required by the law but have not been systematically enforced", corresponded to stage 1 . The statement describing stage 2 was "in addition to the equality statement, 1-2 projects relating to equality have been executed. For example, an analysis of gender-based salaries. We are in general working objectively with gender equality on the board and in committees." The statement reflecting organizations that are reaching upper stages and should thus be positively affecting employees' perceptions through their actions, was "A minimum of 3-4 active projects in the field of equality (in addition to the equality statement), equality in regard to positions, wages, training and progression. The composition of management reflects the composition of the workforce." To describe stage 4 the following statement was applied: "We are seeking to actively use human resources effectively and analyze operations with 'gender-glasses'. Various activities are used to ensure equality and the organization has received acknowledgement or certification from a neutral agent in the field of equality within the last 5 years." The question on the existence of the equality statement in the organization was also used for validation purposes for organizations to be placed at stage 1 of OEM.

The answers from the HR directors were recoded into a dichotomous variable dividing organizations into two groups: those that scored 2 and lower (low on Organizational Equality Maturity) and those that were more active and effective, scoring 3 and above on the Equality Maturity scale (high on OEM). A total of 8 organizations out of 35 participating in this study (23\%) were classified with high OEM. The higher ranking organizations employed 250 employees, or $24 \%$ of the respondents. Hence, a majority of the respondents were organizations that ranked low on OEM, most of them only possessing an equality statement but little beyond that minimal legal requirement.

For the data collection amongst employees, a construct was designed to measure employee perceptions of equality. Participants evaluated 9 positively presented statements on a 5-point Likert scale, where $1=$ strongly disagree, $2=$ disagree, $3=$ neither disagree nor agree, $4=$ agree, $5=$ strongly agree. Three of the items used within this construct were developed by Moore, Parkhouse and Konrad (2010) and classified by them as a philosophical support. They primarily measure top management's image as an equality employer by employees, for example “The organization's reputation as an equal opportunity employer 
is important to the top management." Six more substantive HRM items were added to this construct, five of which were developed by the researchers (items no. 4-8 in tables 3 and 4), for example "Objectives are set and taken into account for gender balance in hiring and promotions." The statements were intended to reflect equality activity within five key HRM domains (staffing, performance management, training and development, compensation and communication). To determine whether employees feel involved in decision-making at their workplace the following item developed by Nickel (1995) was added: "At work, both women and men participate equally in decision-making." The alpha reliability for Perceived Equality was $\alpha=.92$, indicating acceptable reliability (Hair, Anderson, Tatham, \& Black, 1998; Robinson, Shaver, \& Wrightsman, 1991) for the construct of perceived gender equality used here. The items are presented in shorter versions in the results presented in Tables 3 and 4.

The unit of analysis is multilevel and variables from both datasets were used to perform statistical analyses, correlations, t-tests and a multiple hierarchical regression. The effect size of t-tests were evaluated with Cohen's d. Results are interpreted verbally as suggested by Cohen (1988), or $\mathrm{d}<0.3$ as a small effect, between $0.3-0.5$ as a medium effect, $0.6-0.8$ as a large effect. Values acquired at the organizational level, on the existence of an equality statement and about Organizational Equality Maturity (OEM), are therefore disaggregated for each firm, and the values acquired at the organizational level were assigned to the respective individual employees of the firm.

\section{Results}

Preliminary descriptive statistics, with means, standard deviations and correlations between key constructs of the study, or the existence of an equality statement and Organizational Equality Maturity (OEM) at the organizational level and overall perceived equality at the employee level are reported in Table 1. Also shown are the values of three key background variables: gender, education and management responsibility. These are followed by the results of $\mathrm{t}$-tests and effect sizes comparing employee perceptions of equality (means). These are shown first for both organizations with an equality statement and for those without (Table 2), and then between organizations scoring low versus high on equality maturity (Table 3). Finally, the results of the multiple hierarchical regression analysis results are shown (Table 4).

As expected, Table 1 shows that the existence of an equality statement had a significant positive relationship with equality maturity at the organizational level. There was also a positive, although not significant, relationship between equality maturity and overall perceived equality of employees. However, equality maturity had a significant positive correlation with overall perceived equality by employees. Both the existence of an equality statement and equality maturity had a positive significant relationship with gender, while the relationship between gender and overall perceived equality is significantly negative. It indicates that women perceive organizational equality as lower than men. Gender is also significantly negatively related to management responsibility.

A positive relationship was between perceived equality and level of education as well as with management responsibility. Employee educational level has a significant positive relationship with the existence of an equality statement. 
Table 1. Descriptive statistics and correlations $(n=1041)$

\begin{tabular}{|c|c|c|c|c|c|c|c|c|}
\hline & $\mathrm{M}$ & SD & 1 & 2 & 3 & 4 & & 5 \\
\hline \multicolumn{9}{|l|}{ Organizational level constructs } \\
\hline 1. Existence of equality statement & 0.880 & 0.324 & & & & & & \\
\hline 2. Equality maturity & 0.271 & 0.444 & $0.211^{* *}$ & & & & & \\
\hline \multicolumn{9}{|l|}{ Employee level construct } \\
\hline 3. Overall perceived equality & 3.727 & 0.777 & 0.035 & $0.139^{* *}$ & & & & \\
\hline \multicolumn{9}{|l|}{ Bakground variables } \\
\hline 4. Gender $(0=$ men \& $1=$ women $)$ & 0.549 & 0.498 & $0.122 * *$ & $0.096^{* *}$ & $-0.172 * *$ & & & \\
\hline 5. Level of education ( $0=$ Not univ. \& $1=$ Univ.) & 0.593 & 0.492 & $0.238^{* *}$ & 0.064 & $0.120^{* *}$ & 0.055 & & \\
\hline 6. Management responsibility $(0=\mathrm{No} \& 1=\mathrm{Yes})$ & 0.350 & 0.477 & -0.013 & -0.027 & $0.166^{* *}$ & -0.163 & $* *$ & $0.166^{* *}$ \\
\hline
\end{tabular}

$\mathrm{M}=$ mean; ${ }^{*} \mathrm{p}<.05 .{ }^{* *} \mathrm{p}<.001 . \mathrm{SD}=$ Standard deviation

Independent-sample t-tests were executed to compare the employee equality perception scores for organizations with no equality statement and those with one (see Table 2). There was no significant correlation between equality statement existence and employee overall perception of equality. However, the existence of an equality statement had a significant positive correlation with three sub-items of the employee perception scale (items 1, 3 and 4). These are employee evaluations on whether top management values its reputation as an equality employer, evaluations on whether top management actively attempts to comply with legal equality requirements, and whether objectives are set for gender equality and addressed in hiring and promotions. In most cases the difference was in the direction of a higher evaluation when an equality statement exists, except for the cases of evaluations of employee performance, fairness of compensation and women participating equally in decision-making (items 5, 8 and 9), where the difference is not significant. In addition, Cohen's d shows a small effect size for these three significant items, ranging from 0.220.29 , describing the strength of association between variables, independent of sample size.

Table 2. t-test results - comparing organizations with equality statement to those without

\begin{tabular}{|c|c|c|c|c|c|c|}
\hline & $\begin{array}{c}\text { No equality } \\
\text { statement } \\
M(\mathrm{Sd})\end{array}$ & $\begin{array}{c}\text { Equality } \\
\text { statement } \\
\mathrm{M}(\mathrm{Sd})\end{array}$ & $\mathrm{df}$ & $\mathrm{t}$ & $p$ & $\begin{array}{c}\text { Cohen's } \\
\text { d }\end{array}$ \\
\hline Overall perceived equality - by employees & $3.65(0.79)$ & $3.74(0.77)$ & 983 & -1.113 & 0.266 & 0.11 \\
\hline 1. Top management values reputation as equality employer & $3.63(0.97)$ & $3.84(0.96)$ & 979 & -2.190 & 0.029 & 0.22 \\
\hline 2. Top management has been leading in providing equal opportunities for women & $3.66(0.99)$ & $3.69(1.02)$ & 977 & -0.308 & 0.758 & 0.03 \\
\hline 3. Top management actively attempts to comply with legal requirements & $3.46(0.92)$ & $3.71(0.96)$ & 974 & -2.660 & 0.008 & 0.27 \\
\hline 4. Objectives are set about gender equality and addressed in hiring and promotions & $3.07(0.91)$ & $3.33(0.92)$ & 967 & -2.868 & 0.004 & 0.29 \\
\hline 5. Employee performance is evaluated systematically and unrelated to gender & $3.67(1.02)$ & $3.62(1.04)$ & 988 & 0.490 & 0.624 & -0.05 \\
\hline 6. Women and men have equal access to training and development & $3.85(1.03)$ & $3.94(0.99)$ & 973 & -0.870 & 0.385 & 0.09 \\
\hline 7. Information is shared equally to all employees, regardless of gender & $4.05(1.00)$ & $4.10(0.95)$ & 976 & -0.476 & 0.634 & 0.05 \\
\hline 8. Compensation is fair for both genders & $3.66(1.01)$ & $3.57(1.06)$ & 972 & 0.836 & 0.403 & -0.08 \\
\hline 9. Women and men participate equally in decision-making & $3.81(1.07)$ & $3.81(1.03)$ & 979 & 0.015 & 0.988 & 0.00 \\
\hline
\end{tabular}

$\mathrm{Sd}=$ Standard deviation $-\mathrm{Df}=$ degree of freedom

$\mathrm{n}=1041$

As can be seen in Table 3, organizations scoring high on Organizational Equality Maturity (OEM) received a significantly higher mean evaluation on equality by their employees, with a Cohen's d effect size of 0.32 . In all cases, employees in organizations with a higher equality maturity evaluated these different aspects higher than employees in organizations with lower levels of maturity. The strongest, or medium effect sizes, can be seen for employee evaluations of top management actively attempting to comply with legal requirements (0.46), top management valuing their reputation as an equality employer (0.39), objectives set for gender equality and addressed in hiring and promotions (0.39), and top management leading in providing equal opportunities for women (0.35) (items 1, 2, 3 and 4). The effect was stronger for the image-related items of the questionnaire than 
the ones referring directly to specific HRM practices (items 5-9). Cohen's d for other items used to measure employee perceptions are below the threshold of 0.20 for a small effect, provided by Cohen (1988).

Table 3. t-test results - comparing organizations with low and high equality maturity

\begin{tabular}{|c|c|c|c|c|c|c|}
\hline & $\begin{array}{c}\text { Low } \\
\text { maturity } \\
\mathrm{M}(\mathrm{sd})\end{array}$ & $\begin{array}{c}\text { High } \\
\text { maturity } \\
\mathrm{M}(\mathrm{sd})\end{array}$ & $\mathrm{df}$ & $\mathrm{t}$ & $p$ & $\begin{array}{c}\text { Cohen's } \\
\text { d }\end{array}$ \\
\hline Overall perceived gender equality - by employees & $3.69(0.78)$ & $3.94(0.75)$ & 875 & -4.163 & 0.000 & 0.32 \\
\hline 1. Top management values reputation as equality employer & $3.74(0.97)$ & $4.11(0.89)$ & 872 & -5.006 & 0.000 & 0.39 \\
\hline 2. Top management has been leading in providing equal opportunities for women & $3.62(1.03)$ & $3.97(0.95)$ & 869 & -4.452 & 0.000 & 0.35 \\
\hline 3. Top management actively attempts to comply with legal requirements & $3.60(0.98)$ & $4.03(0.85)$ & 867 & -5.806 & 0.000 & 0.46 \\
\hline 4. Objectives are set about gender equality and addressed in hiring and promotions & $3.24(0.91)$ & $3.60(0.94)$ & 860 & -5.033 & 0.000 & 0.39 \\
\hline 5. Employee performance is evaluated systematically and unrelated to gender & $3.65(1.02)$ & $3.74(1.07)$ & 872 & -1.186 & 0.236 & 0.09 \\
\hline 6. Women and men have equal access to training and development & $3.91(0.99)$ & $4.09(1.00)$ & 868 & -2.303 & 0.022 & 0.18 \\
\hline 7. Information is shared equally to all employees, regardless of gender & $4.08(0.98)$ & $4.21(0.88)$ & 868 & -1.876 & 0.061 & 0.15 \\
\hline 8. Compensation is fair for both genders & $3.57(1.05)$ & $3.74(1.06)$ & 865 & -2.153 & 0.032 & 0.16 \\
\hline 9. Women and men participate equally in decision-making & $3.80(1.02)$ & $3.95(1.07)$ & 873 & -1.838 & 0.066 & 0.14 \\
\hline \multicolumn{7}{|c|}{ Low maturity $=$ organizations on stage 2 and below on gender equality maturity scale } \\
\hline \multirow{2}{*}{\multicolumn{7}{|c|}{ High maturity $=$ organizations on stage 3 and above on gender equality maturity scale }} \\
\hline & & & & & & \\
\hline
\end{tabular}

Table 4 shows the results of the hierarchical multiple regression analysis of the data. The table shows that the results in the previous tables were robust for controlling for background variables such as gender, education and management responsibility. Together the background variables explained $6 \%$ of the variance in overall employee perceptions of equality. The OEM explained an additional 2.3\% of the variance in employee perceptions of gender equality. The existence of an equality statement does not have any explanatory power, while reaching stage 3 of OEM has a significant positive effect on employee perceptions of equality, controlling for gender, education, and management responsibility. The results show that having a higher education and management responsibility go hand in hand with a higher perception of gender equality. However, women perceive less gender equality than men when controlling for OEM.

Table 4. Hierarchical multiple regression - explanatory power of organizational activity and employee characteristics on overall employee perceptions of equality

\begin{tabular}{lcccc}
\hline & \multicolumn{2}{c}{ Model 1 } & \multicolumn{2}{c}{ Model 2 } \\
\hline & $\boldsymbol{B}$ & $\mathrm{SE}$ & $\boldsymbol{B}$ & $\mathrm{SE}$ \\
\hline (Constant) & $3.694^{* * *}$ & 0.053 & $3.633^{* * *}$ & 0.082 \\
Bakground variables & & & & \\
Gender & $-0.246^{* * *}$ & 0.053 & $-0.268^{* * *}$ & 0.053 \\
Education & $0.172^{* *}$ & 0.054 & $0.156^{* *}$ & 0.055 \\
Management responsibility & $0.198^{* * *}$ & 0.056 & $0.204^{* * *}$ & 0.056 \\
Organizational level activity & & & & \\
Existing equality statement & & & 0.006 & 0.060 \\
Organizational equality maturity & & & $0.266^{* * *}$ & 0.060 \\
$\mathrm{R}^{2}$ & 0.060 & & 0.083 & \\
Adjusted $\mathrm{R}^{2}$ & $0.057^{2}$ & & 0.078 & \\
$\mathrm{R}^{2}$ Change & 0.060 & & 0.023 & \\
F for change in R2 & $17.733^{* * *}$ & & $10.421 * *$ & \\
\hline
\end{tabular}

${ }^{*} \mathrm{p}<0.05 ;{ }^{* *} \mathrm{p}<0.01 ;{ }^{* * *} \mathrm{p}<0.001$

Gender $(0=$ men $\& 1=$ women $)$. Level of education $(0=$ not univ. \& $1=$ univ. $)$

Management responsibility ( $0=$ no \& $1=$ yes) 


\section{Discussion}

The main objective of this study was to evaluate the effect of the existence of the legally required gender equality statement and of Organizational Equality Maturity (OEM) on employee perceptions of gender equality. When organizations decide to emphasize gender equality in their operations, one objective should be that employees be made aware of this policy and perceive it to be effective. In addition, employees are the direct stakeholders of any HRM activity and it has been proposed by Nishii et al. (2008) that employee perceptions precede attitudes in the causal link toward organizational performance. The results revealed that the existence of a gender equality statement in the organization did not affect overall employee perceptions of equality, while OEM positively influenced employee perceptions of equality. Although required by law, some $14 \%$ of the participating organizations did not fulfil this requirement thus indicating a non-commitment to gender equality.

In line with Cornelius (2002), there are indications that a gap may exist between HRM hoped-for results among employees in terms of legally required equality activity, as the existense of equality statements in organizations did not affect employee perceptions. It may also indicate that as time passes from legislation, organizational activity becomes more of a general norm and a minimum requirement. Organizations that want to be responsible "citizens" in line with Corporate Social Responsibilty (CSR) may then need to go proactively above and beyond legislation in order to positively affect their employee perceptions of equality. There was a significant positive relationship between the existence of an equality statement in organizations and employee evaluations of top management as equality employer, top management actively attempting to comply with legal requirements, and objectives being set about gender equality and addressed in hiring and promotions. It indicates that the existence of an equality statement may not have an overall effect on employee perceptions of equality, as it is primarily an expected minimum fulfilment of legal requirements. It is also possible that legally required actions are non-proactive, or actions taken half-heartedly without a full commitment on behalf of the organizations. However, it appears that employees still evaluate their employer higher on the more generic image-related items, or what Moore et al. (2010) classified as philosophical support rather than substantive HRM activity, as well as on hiring and promotion practices, when a gender equality statement exists. This may therefore build the foundation for developing into maturity. Hence, the answer to the first research question is that there is a small, positive, albeit non-significant, relationship between the existence of a gender equality statement and overall employee perceptions of equality.

There were indications that Organizational Equality Maturity positively affected overall employee equality perceptions. The largest effects were on perceptions of top management actively attempting to comply with legal requirements, top management valuing its reputation as an equality employer, objectives being set about gender equality and addressed in hiring and promotions, and top management leading in providing equal opportunities for women (in this order). It is worth noting that employees did not seem to be specifically affected in substantive HRM areas other than hiring and promotions, or in areas where discrimination may be more subtle through every-day incidents when information on decision-making is not necessarily transparent or available to employees (Van Laer \& Janssens, 2011). Here it applied to employee perceptions of equality in performance evaluations, access to training and development, information sharing, compensation, and equal participation in decision-making. Thus, increased maturity in itself did not affect employees' perceptions of these more specific substantive HRM actions (except for hiring and promotions) although it affected the overall image of the organization as a law abiding and leading opportunity equal employer, which has been classified as philosophical support by Moore et al. (2010).

The results outlined above, that the existence of a gender equality statement did not affect the perception of equality although the OEM had an effect on employee percep- 
tions, held when controlling for the individual background variables of gender, education, and management responsibility. Hence, the answer to the second research question is that there was a significant positive relationship between maturity and employee perceptions of gender equality. That is, employees seemed to recognize when gender is on the agenda of the management of the organizations and affect their perception of philosophical support in this area. Still, women perceived less gender equality in the workplace than did men, while employees with tertiary education had a more positive view of gender equality, as did those who held management responsibility.

Even though employee perceptions were affected by Organizational Equality Maturity, it primarily affected the image of top management and hiring and promotion practices, but to a lesser extent the perceptions relating to the more substantive HRM-related actions, such as performance evaluations, equal access to training and development, information sharing, fair compensation, and equal opportunities to participate in decision-making. The results therefore indicate room for improvement and an opportunity for organizations to directly tackle more subtle discrimination (Van Laer \& Janssens, 2011) and unconscious biases in decision-making (Karlsson et al., 2007; Moss-Racusin et al., 2012). Organizations may need to become more transparent in their HRM actions and decision-making in order to continue on the path to gender equality (England, 2010; European Commission, 2016; Timmer \& Senden, 2016) and to increase their impact on employee perceptions of equality. In other words, this affects not only the employee stakeholder perceptions of management but also their perceptions of organizational HRM practices. Hence, we suggest that in order to tackle direct, illegal and socially unacceptable discrimination, organizations may need to respond to the general trend and the need for openness and an open-access culture in the workplace for new generations in the labor market, or as suggested by Marasi and Bennett (2016), through increased transparency in decision-making in all HRM domains.

In the Icelandic context, promoting the idea of increased openness, applying article 19 of the Act on Equal Status and Equal Rights of Women and Men (10/2008), which explicitly revokes wage secrecy and states that employees are always allowed to inform others about their wages, may aid in reducing the gender wage differential and affect employees' perceptions of fairness in compensation. Following on the effects of the most recent amendment to the national legislation (Act on Equal Rights of Women and Men (An Equal Wage Certification), 56/2017) directly addressing the gender wage gap and requiring equal wage certification by a third party are a topic for future research. These two legal requirements both address compensation, or the gender wage gap, and may have a positive impact on employee perceptions of equality in relation to compensation. However, it remains to be answered how organizations can combat stereotyping and unconscious bias in the workplace in various other HRM processes and decision-making. That applies to decision-making in training and development, performance evaluations, information sharing and equal participation in decision-making. The results raise the question of how organizations can address equality in these HRM domains and whether some form of transparency might help. It also raises the question as to whether additional legislation should be called for from the government to address more specifically these HRM domains.

\section{Conclusion}

The minimum legal requirement of having a gender equality statement can have some positive effects on employee perceptions of equality, while not making a significant difference. However, going beyond the minimum requirement by management showing that it is proactive and committed to gender equality in the workplace, resonates among employees and reveals their increased overall perception of gender equality in the workplace. Organizational equality maturity thus positively influences employees. There is still opportunity for improvement, and indications point towards the need for organizations to become more transparent in their HRM practices and decision-making related to per- 
formance evaluations, compensation, information sharing, and equal participation in decision-making in order to affect employee perceptions of equality in these domains.

This paper provides new insights into the relationship between gender equality actions on behalf of organizations and employee perceptions of equality. It shows how organizations that are more mature or proactive and committed to their equality activity seem to reap some benefits in the form of more positive employee perceptions of equality. One limitation may be traced to the electronic data collection, which might exclude employees in lower level jobs as they may not use email or computers in their daily work. It may also be noted that perceptions do not always reflect an ultimate reality. However, in this context employee perceptions of equality should matter for organizations that set goals in this area and be important for organizations that want to attract and retain both men and women in their workforce. It is also possible that the results lack generalizability to other countries. Hence, further studies are warranted in different contexts and in other countries, to show whether these results are robust. Also, future studies are needed to follow up on the effects of the most recent amendment to the national legislation which requires equal wage certification by a third party (Act on Equal Rights of Women and Men (An Equal Wage Certification), 56/2017). Controlled experiments within organizations may also aid in answering the questions of which specific gender equality practices are most effective in improving employee perceptions of equality in the workplace.

\section{References}

Act on Equal Rights of Women and Men (An Equal Wage Certification) no. 56/2017 (Lög um breytingu á lögum um jafna stöðu og jafnan rétt kvenna og karla, nr. 10/2008, með síðari breytingum (jafnlaunavottun/ equal wage certification)). Retrieved from https://www.althingi.is/altext/146/s/1054.html

Act on Equal Status and Equal Rights of Women and Men no. 10/2008 (Lög um jafna stöðu og jafnan rétt kvenna og karla nr. 10/2008). Retrieved from https://www.althingi.is/lagas/146b/2008010.html

Bruckmüller, S., Ryan, M. K., Rink, F., \& Haslam, S. A. (2014). Beyond the glass ceiling: The glass cliff and its lessons for organizational policy. Social Issues and Policy Review, 8(1), 202-232.

Carli, L. L., \& Eagly, A. H. (2016). Women face a labyrinth: An examination of metaphors for women leaders. Gender in Management: An International Journal, 31(8), 514-527.

Carroll, A. B. (1999). Corporate social responsibility: Evolution of a definitional construct. Business E Society, 38(3), 268-295.

Centre for Gender Equality. (2017). Eldri jafnréttislög (older acts on equality). Retrieved September 28, 2017, from http://www.jafnretti.is/jafnretti/?D10cID=Page3\&ID=114

Centre for Gender Equality Iceland. (2012). Gender Equality in Iceland - Information on Gender Equality Issues in Iceland. Akureyri: The Centre for Gender Equality Iceland. Retrieved from http://www.jafnretti.is/D10/_ Files/Gender_Equality_in_Iceland_2012.pdf

Constitution of the Republic of Iceland no. 33/1944 (Stjórnarskrá lýðveldisins Íslands nr. 33/1944). Retrieved from http://www.government.is/constitution/

Cornelius, N. (2002). Building workplace equality: Ethics, diversity and inclusion. London: Thomson.

Cranfield Network on International Human Resource Management (Cranet). (n.d.). Home. Retrieved from https://learn.som.cranfield.ac.uk/cranet.

Creegan, C., Colgan, F., Charlesworth, R., \& Robinson, G. (2003). Race equality policies at work: employee perceptions of the 'implementation gap' in a UK local authority. Work, Employment and Society, 17(4), 617-640.

Dickens, L. (1999). Beyond the business case: A three-pronged approach to equality action. Human Resource Management Journal, 9(1), 9-19.

Einarsdottir, A., Bjarnadottir, A., \& Oddsson, F. (2009). Staða mannauðsstjórnunar á Íslandi: Cranet rannsóknin 2009 (SHRM status in Iceland: The Cranet research 2009). Reykjavik: Reykjavik University. Retrieved from http://hdl.handle.net/1946/13188

Einarsdottir, A., Bjarnadottir, A., Olafsdottir, K., \& Georgsdottir, A. K. (2012). Staða og próun mannauðsstjórnunar á Íslandi: Cranet rannsóknin 2012 (SHRM status and development in Iceland: The Cranet research 2012). Reykjavik: Reykjavik University. Retrieved from http://hdl.handle.net/1946/20149

Einarsdottir, A., Olafsdottir, K., \& Bjarnadottir, A. (2015). Staða og próun mannauðsstjórnunar á Íslandi: Cranet rannsóknin 2015 (SHRM Status and development in Iceland: The Cranet research 2015). Reykjavik: Reykjavik University.

Einarsdottir, U. D., Kristjansdottir, E., \& Christiansen, P. H. (2017). ... Hvað segið pið strákar? Upplifun kvenmillistjórnenda af stöðu sinni möguleikum (in Icelandic). Tímarit um viðskipti og efnahagsmál (Research in applied business and economics), 14(1), 1-24. 
Ellemers, N., Rink, F., Derks, B., \& Ryan, M. K. (2012). Women in high places: When and why promoting women into top positions can harm them individually or as a group (and how to prevent this). Research in Organizational Behavior, 32, 163-187.

England, P. (2010). The gender revolution: Uneven and stalled. Gender E Society, 24(2), 149-166.

European Commission. (2016). The Gender Pay Gap in the European Union. Retrieved from http://ec.europa. eu/justice/gender-equality/files/gender_pay_gap/2016/gpg_eu_factsheet_2016_en.pdf

Freeman, R. E. (1984). Strategic management: A stakeholder approach. Boston, MA: Pitman.

Grosser, K. (2009). Corporate social responsibility and gender equality: Women as stakeholders and the European Union sustainability strategy. Business Ethics: A European Review, 18(3), 290-307.

Hair, J. E., Anderson, R. E., Tatham, R. L., \& Black, W. C. (1998). Multivariate data analysis. Upper Saddle River, NJ: Prentice Hall.

Karlsson, P., Jonsdottir, M., \& Vilhjalmsdottir, H. (2007). Kvennnafn lækkar launin: Tilraun á mögulegum skýringum á óútskýrðum launamuni karla og kvenna (Female name decreases wages - an experiment). Reykjavík: Reykjavik University. Retrieved from https://rafhladan.is/bitstream/handle/10802/6597/Kvennanafn-laekkarlaunin_2007.pdf?sequence=1

Kearns, P. (2003). HR strategy: Business focused, individually centred. Amsterdam; Boston: Butterworth-Heinemann.

Kearns, P. (2010). HR strategy: Creating business strategy with human capital. Oxford, UK: Butterworth-Heinemann.

MacNell, L., Driscoll, A., \& Hunt, A. (2015). What's in a name: Exposing gender bias in student ratings of teaching. Innovative Higher Education, 40, 291-303.

Marasi, S., \& Bennett, R. J. (2016). Pay communication: Where do we go from here? Human Resource Management Review, 26(1), 50-58.

Moore, M. E., Parkhouse, B. L., \& Konrad, A. M. (2010). Women in sport management: Advancing the representation through HRM structures. Gender in Management: An International Journal, 25(2), 104-118.

Moss-Racusin, C. A., Dovidio, J. F., Brescoll, V. L., Graham, M. J., \& Handelsman, J. (2012). Science faculty's subtle gender biases favor male students. Proceedings of the National Academy of Sciences, 109(41), 1647416479.

Ng, E. S. W., \& Burke, R. J. (2004). Cultural values as predictors of attitudes towards equality and diversity: A Canadian experience. Women in Management Review, 19(6), 317-324.

Nickel, H. M. (1995). Women amid social transformation: the dual transformation in Germany and its ambivalent consequences. Canadian Woman Studies, 16(1), 64-69.

Nishii, L. H., Lepak, D. P., \& Schneider, B. (2008). Employee attributions of the "why" of HR practices: Their effects on employee attitudes and behaviors, and customer satisfaction. Personnel Psychology, 61(3), 503-545.

Oddsson, F., Bjarnadottir, A., \& Einarsdottir, A. (2006). Rannsókn: Mannauðsstjórnun á Íslandi 2006 (Research: HRM in Iceland 2006). Retrieved from http://hdl.handle.net/1946/16698

OECD. (2016). Labour force statistics by sex and age: indicators. Paris: Organisation for Economic Co-operation and Development. Retrieved from http://stats.oecd.org/BrandedView.aspx?oecd_bv_id=lfs-data-en\&doi=data-00310-en

Olafsdottir, K. (2018). Iceland is the best, but still not equal. Sökelys på arbeidslivet, 35(1-2), 111-126.

Olafsdottir, K., \& Rognvaldsdottir, S. (2015). Staða karla og kvenna á íslenskum vinnumarkaði - Staðreyndir og staða pekkingar (Status of Men and Women in the Icelandic Labour Market). Reykjavík: Velferðarráðuneyti (Ministry of Welfare). Retrieved from https://www.velferdarraduneyti.is/media/rit-og-skyrslur-2015/Stada_karla_og_kvenna_29052015.pdf

Robinson, J. P., Shaver, P. R., \& Wrightsman, L. S. (1991). Criteria for scale selection and evaluation. In J. P. Robinson, P. R. Shaver, \& L. S. Wrightsman (eds.), Measures of personality and social psychological attitudes (Vol. 1, pp. 1-16). San Diego, CA: Academic Press. Retrieved from on\&ots=3H4NITv3-L\&sig=1J0O6uhq-H1IeGkHxdx3ytNqyx4

Snaevarr, S. (2015). Launamunur karla og kvenna (Gender wage differential). Reykjavík: Velferðarráðuneyti (Ministry of Welfare). Retrieved from https://www.stjornarradid.is/media/velferdarraduneyti-media/media/ritog-skyrslur-2015/Launamunur_karla_og_kvenna_19052015b.pdf

Statistics Iceland. (2017a). Fjöldi starfandi eftir menntun (Number employed by education). Retrieved October 6, 2017, from http://px.hagstofa.is/pxis/pxweb/is/Samfelag/Samfelag_vinnumarkadur_3_arstolur/ VIN01100.px/table/tableViewLayout1/?rxid=82dc8070-bcf0-4943-89b9-907b3dbddf50

Statistics Iceland. (2017b). Fjöldi starfandi eftir starfsstéttum, kyni og menntun 1991-2016 (number in the labour market by gender). Retrieved from http://px.hagstofa.is/pxis/pxweb/is/Samfelag/Samfelag_vinnumarkadur_3_arstolur/VIN01100.px/table/tableViewLayout1/?rxid=e6d4b282-99d0-4078-ba22-8252fa625 fe5

Statistics Iceland (2018). Framkvæmdastjórar og stjórnarmenn fyrirtækja eftir kyni 2016. (Directors and board members of organizations by gender in 2016). Retrieved from http://px.hagstofa.is/pxis/pxweb/is/Atvinnuvegir/Atvinnuvegir_fyrirtaeki_fjoldi_stjornir/FYR06101.px/table/tableViewLayout1/?rxid=c7195231 -e7d1-473b-9dfa-c1fa254ba6ef

Timmer, A. S. H., \& Senden, L. A. J. (2016). A comparative analysis of gender equality law in Europe 2016. Pub- 
lications Office of the European Union. Retrieved from https://dspace.library.uu.nl/bitstream/handle/1874/348449/2016.pdf?sequence=1

United Nations. (n.d.). Sustainable Goals - 17 goals to transform our world. Retrieved from http://www.un.org/ sustainabledevelopment/gender-equality/

Van Dijk, H., Van Engen, M., \& Paauwe, J. (2012). Reframing the business case for diversity: A values and virtues perspective. Journal of Business Ethics, 111(1), 73-84.

Van Laer, K., \& Janssens, M. (2011). Ethnic minority professionals' experiences with subtle discrimination in the workplace. Human Relations, 64(9), 1203-1227.

Verloo, M. M. T. (2005). Mainstreaming gender equality in Europe: A critical frame analysis approach. Greek Review of Social Research, 117, 11-34. Retrieved from http://repository.ubn.ru.nl/bitstream/handle/2066/165981/165981.pdf

World Economic Forum. (2016). The Global Gender Gap Report 2016 (Insight Report). Retrieved from https:// www.weforum.org/reports/the-global-gender-gap-report-2016/

Zanoni, P., Janssens, M., Benschop, Y., \& Nkomo, S. (2010). Guest Editorial: Unpacking Diversity, Grasping Inequality: Rethinking Difference through Critical Perspectives. Organization, 17(1), 9-29. https://doi. org/10.1177/1350508409350344 


\section{Appendix A}

A1. Evaluate the five scenario statements and select the one that BEST describes that status in equality matters within the organization

\begin{tabular}{|c|c|c|}
\hline $\begin{array}{l}\text { Coding/ } \\
\text { Stages }\end{array}$ & Icelandic - Scenario statements & English translation \\
\hline 0 & $\begin{array}{l}\text { Ekki til jafnréttisstefna, hvorki sem hluti af } \\
\text { starfsmannastefnu né sértæk stefna, og ekki verið } \\
\text { ráðist í neinar aðgerðir á sviði jafnréttismála. }\end{array}$ & $\begin{array}{l}\text { Equality statement does not exist, neither as a part } \\
\text { of HRM nor as a special policy, and no specific } \\
\text { activities have been implemented in the field of } \\
\text { equality }\end{array}$ \\
\hline 1 & $\begin{array}{l}\text { Til staðar skrifleg jafnréttisstefna og/ } \\
\text { eða aðgerðaráætlun um jafnréttismál (eða } \\
\text { starfsmannastefna sem tekur á jafnréttismálum), í } \\
\text { samræmi við lög en ekki verið fylgt markvisst eftir. }\end{array}$ & $\begin{array}{l}\text { Written equality statement exists and/or procedures } \\
\text { exist about equality (or HRM policy which covers } \\
\text { equality) as required by the law but have not been } \\
\text { systematically enforced. }\end{array}$ \\
\hline 2 & $\begin{array}{l}\text { Auk jafnréttisstefnu verið ráðist í 1-2 verkefni, t.d. } \\
\text { greiningar á launum eftir kyni. Almennt markvisst } \\
\text { unnið með kynjajöfnun í stjórn og nefndum. }\end{array}$ & $\begin{array}{l}\text { In addition to equality statement, } 1-2 \text { projects } \\
\text { relating to equality have been executed. For } \\
\text { example, an analysis of gender-based salaries. In } \\
\text { general we are working objectively with gender } \\
\text { equality on the board and in committees. }\end{array}$ \\
\hline 3 & $\begin{array}{l}\text { Að lágmarki 3-4 aðgerðir í gangi á sviði } \\
\text { jafnréttismála auk jafnréttisstefnu), jafnrétti til starfa, } \\
\text { launa, pjálfunar og framgangs. Stjórnendur til } \\
\text { fyrirmyndar og stjórn og stjórnendahópur spegla vel } \\
\text { heildarsam-setningu starfsmannahóps. }\end{array}$ & $\begin{array}{l}\text { A minimum of } 3-4 \text { active projects in the field } \\
\text { of equality (in addition to equality statement), } \\
\text { equality in regards to positions, wages, training } \\
\text { and progression. The composition of management } \\
\text { reflects the composition of the workforce. }\end{array}$ \\
\hline 4 & $\begin{array}{l}\text { Leitast er markvisst við að nýta mannauð vel og } \\
\text { greina rekstur með kynjagleraugum. Ýmsar aðgerðir } \\
\text { nýttar til að tryggja jafnrétti og fyrirtækið hlotið } \\
\text { viðurkenningu eða vottun frá óháðum aðila á sviði } \\
\text { jafnréttismála á sl. } 5 \text { árum. }\end{array}$ & $\begin{array}{l}\text { We are seeking to actively use human resources } \\
\text { effectively and analyze operations with "gender- } \\
\text { glasses." Various activities are used to ensure } \\
\text { equality and the organization has received } \\
\text { acknowledgement or certification from a neutral } \\
\text { agent in the field of equality within the last } 5 \text { years. }\end{array}$ \\
\hline
\end{tabular}


